\title{
META-COMPETENCY OF HUMAN RESOURCES IN IMPROVING SERVICE QUALITY IN PHARMACY DEPARTMENT OF RSUD KLUNGKUNG
}

\author{
Priatna I Gusti Bagus Ngurah Harry Dharma*, Gorda Anak Agung Ngurah Oka \\ Suryadinatha \\ Undiknas Graduate School, Bali, Indonesia \\ *E-mail: ghostufd@gmail.com
}

\begin{abstract}
The hospital is a service company, where the product is intangible and comes from the service provider which in this case is the officer or human resources (HR). Human factors still play an important role for the success of an organization. Every individual is required to explore all the human resources they have, to be able to support performance, so that it affects the service every day. Talking about the problem of human resources is of course related to competence. Pharmacy services are one of the medical support services in the hospital. In addition to procuring, managing and distributing logistics in hospitals, pharmaceutical installations also provide pharmaceutical / nursing services to patients, so that the distribution of drugs to patients can run well. But in reality there are internal problems on the ground which later leads to complaints from the community / patient. The problem is when employees are required to work optimally but in reality is inversely proportional to the minimal situation both in terms of facilities and human resources. Responding to this phenomenon, it is necessary to do research on the implementation of Meta-competency of human resources in improving the quality of services in hospitals, we are expected to be multi-tasking at work. This research is descriptive qualitative study; the data source is in the form of primary data (interviews, observations), secondary data (literature study and documentation), determination of informants by purposive sampling technique, criteria-based selection. We are using source and technique triangulation as examination and validity techniques. The conclusion of the study was that in RSUD Klungkung implemented a metacompetency to improve the quality of services in RSUD Klungkung, especially in Pharmacy Installation, as shown by the results of interviews with several informants who were considered to represent the research. As stated by the head of the installation, employees at pharmacy installations have been multitasking their jb, besides being accustomed to adapting to their work, also supported by training, as well as seminars that enrich the competencies possessed by these resources, evidenced by the existence of certificates that prove that the source the power is participating in the training.
\end{abstract}

\section{KEY WORDS}

Human resources, competence, meta-competence, service quality.

The hospital is a unique organization, which is a combination of technology-intensive, labor-intensive and capital-intensive. Hospital management becomes a separate scientific discipline that produces two things at once, namely technology and human behavior in organizations (Subanegara, 2005). The hospital is a service company, where the products produced are intangible and originate from these service providers which in this case are officers or human resources (Djuhaeni, 1993).

The importance of HR needs to be realized by all levels of management, even with current technological advances, the human factor still plays an important role for the success of an organization (WHO, 2003). This is consistent with the results of Chilgren's research (2008) which states that the quality of service expected by patients includes: speed of service time, attitudes and behavior of employees (doctors and other employees), as well as clarity of information provided. To produce quality services in accordance with patient expectations, HR competencies, especially HR that are directly related to the care process are very important. HR competency in serving patients is not only seen from their expertise 
and knowledge, but also through their emotional condition. Speaking of HR issues is of course related to competence. Competence is generally defined as a combination of knowledge, skills, and behavior (attitude) of an employee so that he can carry out his work. Many experts are of the opinion that quality human resources will determine the success or failure of an organization with the competence of every existing employee.

The quality of hospital services in Indonesia especially government hospitals is still felt unsatisfactory. Complaints occur not only in the aspect of infrastructure, but also factors in human resources (HR). The waiting time for patients to be served is often very late and not according to the prescribed practice schedule (Jonirasmanto, 2009) For patients, the quality of services provided by hospital personnel accelerates their recovery (Karassavidou et al, 2009). Regional General Hospital (RSUD) of Klungkung Regency is a Klungkung government-owned hospital located on Jalan Flamboyan No. 40 Semarapura. On December 1, 2016 the Klungkung Regency Hospital was recognized as having fulfilled the 2012 Version of Hospital Accreditation Standards and was declared to have passed the Plenary Level (Five Star) by the Hospital Accreditation Commission (KARS). Furthermore, on January 23, 2017 through Governor's Decree No. 440 / 844.6 / DPMPSP-H / 2017 concerning Operational Permits for Class B Public Hospitals. After a visitation by the Ministry of Health of the Republic of Indonesia in 2018, the Klungkung District Hospital was designated as a satellite teaching hospital, according to the Decree of the Minister of Health Number: HK.01.07 / MENKES / 732/2018 concerning the Establishment of the Klungkung District General Hospital as a Satellite Education Hospital for the Faculty of Medicine at the Al-Azhar Islamic University of Mataram on December 31, 2018.

Pharmacy service is one of the medical support services, and pharmaceutical installation is the only installation that carries out procurement, management, and distribution of logistics in hospitals. In addition to conducting procurement, management and distribution of logistics in hospitals, pharmaceutical installations also provide pharmaceutical services / pharmaceutical care to patients, so that the distribution of drugs to patients can run well. But in reality on the ground there are internal problems which will eventually lead to complaints from the community / patients. That problem is when employees are required to work optimally but the reality is inversely proportional to the minimal conditions both in terms of facilities and human resources.

Employees are required to innovate with the limitations they have, they need even higher competencies in order to get around this shortcoming. With the minimal number of personnel hampering service, the hospital management has not been able to add staff / employees because it is related to the budget. The Pharmacy Installation staff are required to work optimally and are versatile (multi-tasking) at work. In response to this phenomenon, it is necessary to do research on Meta-human resource competencies in improving the quality of services in hospitals, ordinary competencies are no longer a solution of this problem, we are expected to multi-tasking in working and have higher competencies, we are required not to only have one competency, especially in the digital era like today, besides we have competencies according to our professional field, we are required to be multi-competent, for example from competency management, or digital competence. This means that in addition to being smart and agile in the field of pharmacy, we must also be smart in doing time management, work management, and smart in operating computers so that pharmaceutical services can run smoothly even if done by even a few personnel.

\section{LITERATURE REVIEW}

Human capital in language is composed of two basic words, human and capital. Capital is defined as a factor of production used to make an item or service without consuming it during the production process. Based on the definition of capital, humans in human capital are a form of capital as well as machinery and technology. Humans also have a role or responsibility in all economic activities, such as production, consumption, and transactions. As this theory develops, the concept of human capital can be defined into three. The first concept is human capital as an individual aspect. This concept states that human capital is 
an ability that exists in humans, such as knowledge and skills. This is made clear by Rastogi (2002) states that human capital is knowledge, competencies, attitudes, health, and properties possessed by humans.

Todaro (2000) revealed that human capital can be measured through education and health. Education and training can be an added value to humans. This can be explained if the higher a person's education or the more training he has, the higher his abilities and skills. Meanwhile, health is an interrelated field of education. Higher education that is owned without a healthy body will not increase productivity. Meanwhile, higher education can also affect one's level of health awareness. Todaro (2000) revealed that human capital can be measured through education and health. Education and training can be an added value to humans. This can be explained if the higher a person's education or the more training he has, the higher his abilities and skills. Meanwhile, health is an interrelated field of education. Higher education that is owned without a healthy body will not increase productivity. Meanwhile, higher education can also affect one's level of health awareness.

Human capital is an added value for companies in the company every day, through motivation, commitment, competence, and effectiveness of teamwork, added value that can be contributed by workers in the form of: competency development owned by the company, transferring knowledge from workers to the company and changing management culture (Mayo 2000 in Rachmawati et al. 2004). Andrew Mayo in Ongkodihardjo (2008: 40) defines "human capital as a combination of genetic inheritance, education, experience, and behavior about life and business". Based on the opinion above, it can be concluded that human capital is everything about humans with all the capabilities they have, so as to create value for the organization to achieve its goals.

Human Capital Management (HCM) is described as "a strategic approach to managing people who focus on the very important issue of organizational success". This places human management at a high level of strategic issue and is seen as a systematic method of analysis, measurement and evaluation in making a policy and creating a value. Brown (1994) argues that HCM does not only focus on measurement, but also on how to demonstrate and apply relevant measurements, by combining and interpreting the results of these measurements and also using this information to benefit the strategy, in also conveying companies that try to apply this as much as possible will be able to put the right position in directing policy towards its workers with a continuous strategy. A good HCM is able to create an atmosphere of learning, mutual understanding, and participation in the organization. An organization needs a way to direct the application of HCM policies that can provide added value by meeting their aspirations and needs. This is in line with the assessment and reporting process, but it is important to note important evaluations through the assessment of quantitative and qualitative data and to be used to analyze.

The importance of HR needs to be recognized by all levels of management, even with current technological advances, the human factor still plays an important role for the success of an organization. Meta-Competence is the overall ability of competence. Includes higher order skills that have to do with being able to learn, adapt, anticipate, and create. Metacompetence is a prerequisite for capacity development such as assessment, intuition and intelligence. Competence refers to performance and the ability to use procedures in various stages of the assistance process and include the ability in direct practice, to form collaborative relationships, to conduct assessments, and to implement interventions with clients and systems, whereas Competency Meta refers to a higher order, the overall quality and abilities of conceptual, interpersonal, and personal or professional abilities.

In this study to obtain information, then the data collection was carried out in three ways, namely conducting preliminary observations whose purpose is to see an overview of the implementation of metacompetence, and document review and interviews will be conducted to obtain more specific and accurate data. In the document review, it can be seen the extent of competence possessed by employees. Interviews were conducted to clarify and reinforce the data that had been obtained. By conducting interviews the information obtained is expected to be more complete and clear. It is expected that by conducting observations, document reviews and interviews it will be known how the implementation of 
metacompetence in the Klungkung Regional Hospital Pharmacy Installation. After the interview, the validity of the data is checked so that the data received is correct. Data analysis was carried out after the researcher was sure that all data received was true and valid.

\section{METHODS OF RESEARCH}

Based on the problem formulation and research objectives, this research can be categorized as a descriptive qualitative research. Informants were determined based on purposive sampling technique using criterion based selection, where the number of informants was determined by the researcher based on certain considerations. The main consideration in determining the informant is the mastery of information and data that the author needs. Credibility Test is conducted using Triangulation. Triangulation is a data analysis approach that synthesizes data from various sources in various ways, and at various times. Thus there is a triangulation of sources, techniques, and time. Triangulation is not intended to seek the truth, but to increase the understanding of researchers of the data and facts they have.

\section{DISCUSSION OF RESULTS}

Implementation of meta-competence of human resources in the context of improving the quality of service at the Klungkung Regional Hospital (in the Pharmacy Installation), where informants explained the problems that occur in pharmaceutical installations, the number of complaints due to late delivery of drugs to patients, not to mention demands from the hospital accreditation committee (KARS) to distribute drugs by UDD (Dose Dispensing unit). Dose Dispensing Unit (UDD) is a drug distribution system for inpatients prepared in the form of divided doses ready for use for 24 hours use. Whereas in the field the number of human resources is limited, inevitably, the role of human resources is maximized, they are required to be versatile, multi-talented / multi-tasking and multi-competence to carry out these services so that the quality of work can be maximized and certainly minimize complaints. Pharmacy installation is a service that prioritizes services, so HR is the most important asset in the service. As stated Mustofadidjaja, (2003) that the human resource factor is an important determinant in the process of achieving organizational goals, provided that the human being has the competency according to the qualifications needed. In line with the theory of human capital, in a journal human capital approach to increasing productivity of human resources management written by Iwan Sukoco and Dea Prameswari discusses the human capital approach to managing more productive human resources. Realizing the importance of the role of human resources in company activities, companies should need to manage human resources as well as possible because the key to a company's success is not only in technological excellence and the availability of funds, but also in its human factors.

Talking about HR certainly has to do with competence. Normatively it can be stated from the Minister of Education Decree No. 045 / U / 2002 states that competence is a set of smart and responsible actions owned by a person as a condition to be considered capable by the community in carrying out tasks in certain fields of work. The reliability of HR competencies can be formed with the organization's ability to manage HR into several specifications of individual competencies, among others, the achievement of goal competencies, problem solving competencies, interaction competencies with others and teamwork competencies. Thus, the synergy of the competencies of each individual will optimize the overall organizational performance. In the end, the role of HR competence determines the organization's progress in creating competitive advantage. In line with Ria Mustika Drina's journal, entitled "The Effect of HR Competence and Organizational Culture on Performance, concludes that HR competencies have a positive relationship on organizational performance. Two variables tested have a positive and significant relationship 
between HR competencies and Organizational Performance. Informants also connect competence with the quality of a service.

In a journal entitled "Development of human resource competencies in order to improve services at the Hajj Hospital in Surabaya", written by Falih Suaedi in 2017 concluded that investment in human resources is indeed a concept of human capital, a company that relies on human capital as a strategic resource will invest in these resources through a variety of training and development costs. Hasibuan, (2001: 68), argues that competency development is an effort to improve employee knowledge, technical abilities, and morale according to job needs and this can be done through education education, and various types of training.

In the interview it was also said that the informant innovated by changing work hours and employee shifts, as a result of the lack of human resources. In meta-competence, innovation is very important. Brown (1994) distinguishes between competence and metacompetence. Thus meta-competence implies a higher order ability that must be done by being able to learn, adapt, anticipate, and be creative / innovative.

According to recent researchers, at this time a single competency is no longer sufficient, it needs more up to date and more (diverse) competencies that need to be explored, especially in today's work world, there is not enough just one competency, not to mention the problems that are occur in the world of work, especially in services such as hospitals that very strongly prioritize human resources as the spearhead in maximum service. The application or implementation of meta-competence could be the answer to all these problems.

In addition, they also upgrade their competencies through seminars and trainings both within their workplaces and outside their work environment. Education and training for employees is one of the instruments of coaching. Basically training is a coaching in the process of developing human potential, where humans learn to think for themselves and encourage the development of the basic abilities that are available to them. Therefore it will be more effective if every employee is given training, because training is universal, both government and private organizations. According to Hadipoerwono (1992: 76), that training is coaching skills, skills, dexterity (Skill Building) in the implementation of tasks. Todaro (2000) revealed that education and training can be added value to a human being. This can be explained if the higher a person's education or the more training he has, the higher his abilities and skills.

Mrs. Rusdi's statement referred to in PP (Government's Law) No. 51 of 2009 concerning pharmaceutical work, that Pharmaceutical Technical Workers who have STRTTK (Pharmachist License) have the authority to carry out Pharmaceutical Work under the guidance and supervision of Pharmacists who already have STRA (Apothecary License) in accordance with their education and skills. In this case, Pharmacists are assisted by Pharmaceutical Technical Workers, the implementation of Pharmaceutical services is still carried out by Pharmacists and the responsibility remains with Pharmacists. Pharmacists are professional education after pharmacy graduates. Pharmacists who carry out Pharmaceutical Work must have a certificate of professional competence. Pharmacists who have just graduated from professional education can obtain a certificate of professional competence immediately after registration. The certificate of professional competence is valid for 5 (five) years and can be extended for every 5 (five) years through a professional competency test if the Pharmacist will continue to carry out Pharmaceutical Work.

Based on a journal entitled "Leadership Meta-competencies for the future world of work" written by Lettia Van der Merwe in 2007 concluded that future research assessing perceptions about the nature and work of future business leaders should focus on expanding the pool manifestation of competency behavior at various levels of work complexity. The purpose of this study is to define the nature and work of leaders in the context of the world of work in the future. In line with the journal "Theory of Human Resource Development" written by Afid Nurkholis concluded that Human capital theory uses the concept that the main human capital is education, skills and health. Human investment theory uses the concept of sacrificing something now for more profit in the future. Human development theory is a process to enlarge choices for humans. Sustainable Development Theory is a development 
concept that seeks to meet current needs without compromising future interests. People Centered Development is a development that places people as subjects and objects.

Researchers assume that how complex is the role of a pharmacist in a hospital, a pharmacist must not only be able to provide pharmaceutical services, but is required more than that, there is not enough competency to work in this field, it needs to be multi-competent if you want to carry out this profession, other than proficient in the pharmaceutical field, is also capable in the field of digitalization, such as operating computers, making brochures, and being able to speak publicly in front of people and influence them, to believe and carry out what has been informed. This relates to the theory of Human Capital Management (HCM). HCM is defined as' a management approach of people who treats it as a high-level strategic approach to a problem that is not operational. They define human capital as: stock accumulation of knowledge, skills, experience, creativity and workforce and other relevant attributes show that HCM involves' putting into place metrics to measure the value of these attributes and using that knowledge to effectively manage organizations.

\section{CONCLUSION AND SUGGESTIONS}

Managing human resources (HR) is considered as the main key in improving service quality. Especially in the service at the hospital, this puts $H R$ as the main asset. These assets need to be well prepared in order to be able to make a good and maximum contribution to the organization. HR development has a wider scope in efforts to improve and enhance knowledge, abilities, and attitudes through training. Workforce training for an organization is an important activity where this can affect the level of work productivity and achievement for the workforce itself and for the progress of the organization.

Meta-competence in human resources is also needed so that we are not dependent or pegged to just one person, in other words in one individual, able or able to do other things outside his main field. In the concept of People Development where the company has a system that can accommodate the potential potential possessed by each employee so that employees have good career opportunities, valued and recognized the potential they have which will have an impact on the employee being tied to the job and the company. One component of soft competency that is needed by the company is the ability to work in a team, the Company realizes, in the current condition it is not enough for someone to have good individual abilities, but must have developed towards good teamwork abilities. It is legitimate that someone has multiple competencies, but like the observation of researchers in the ministry of service, teamwork must be maintained and maintained properly. This research is related to the theory of Human Capital and Human Capital management (HCM) because it focuses on humans as assets and integrated efforts to manage and develop human capabilities to achieve higher levels of performance. From the results of the study it was found that the Pharmacy Installation of Klungkung District Hospital had implemented / implemented the HR meta-competency, seen from the results of interviews, observations and documentation, a person's meta-competence was obtained due to circumstances that forced a person to improve his competence so that the quality of his work could improve. in addition to these conditions, meta-competence can be obtained from training - training conducted by companies and professional organizations.

Suggestions that can be given relating to the results obtained as a material consideration, namely the application of meta-competence has been implemented in the pharmaceutical installation of Klungkung Regional Hospital. Teamwork and communication between officers have also been applied. Training - training has been held to support and increase one's knowledge / competence. This Meta-competence could be a solution to the problems faced, but if this has been implemented and maximized but has not been able to improve the quality of service, then maybe the number of human resources is really the main problem. In accordance with the Republic of Indonesia Minister of Health Regulation No. 72 of 2016 concerning hospital pharmacy service standards, Pharmacists who work in hospitals are required to realize the expansion of the Pharmaceutical Services paradigm from product orientation to patient orientation, for that Pharmacist competency needs to be continuously 
improved so that the paradigm change can be implemented, so that in order to achieve the successful implementation of Pharmaceutical Services Standards in Hospitals, a better commitment, cooperation and coordination between the Government, Regional Governments, Professional Organizations and all related parties are needed.

\section{REFERENCES}

1. Brewster, C., Farndale, E., Ommeren, J. V. 2000. HR Competencies and Professional Standards, HR Competencies and Professional Standards Project, Cranfield School Of Management, Cranfield University, UK.

2. Brown, R.B. (1994). Refrain the Competency debate, Manag. Learning, Vol. 25(2), 289299.

3. Chilgren, A. A. 2008. Manager and the New Definition of Quality. Journal of Healthcare Management, 53 (4): 221.

4. Djuhaeni, H, 1993. Manajemen Pelayanan Medis dan Keperawatan, Hospital Management Training, Persi.

5. Hadipoerwono, 1992. Tata Personalia. Djembatan. Bandung.

6. Hasibuan (2001). Manajemen Sumber Daya Manusia. Jakarta: PT. Bumi Aksara.

7. Jonirasmanto. 2009. Mutu Pelayanan Kesehatan: Ambivalensi Antara Kewajiban Dan Keinginan (Antara Penyelenggara Dan Pemilik). Hal Mutu Pelayanan Rumah Sakit/05.11.

8. Karassavidou, E., Glaveli, and N., Papadopoulos, C. T. 2009. Quality In NHS Hospitals: No One Knows Better Than Patients. Measuring Business Excellence J, 13 (1): 34-46.

9. Mayo, Andrew. 2000. "The Role of Employee Development in the Growth of Intellectual Capital, "Personal Review, Vol. 29 No.4, 2000, pp. 521-533.

10. Mustofadidjaja. 2003. Seminar Nasional: Penguatan Administrasi Publik Dalam Rangka Good Governace. STIA LAN. Jakarta.

11. Peraturan Pemerinta RI no 51 tahun 2009 tentang pekerjaan kefarmasian.

12. Peraturan Menteri Kesehatan RI nomer 72 Tahun 2016 tentang Standar Pelayanan Kefarmasian di Rumah Sakit.

13. Rastogi, P. N. 2002. Knowledge Management and Intellectual Capital as a Paradigm of Value Creation. Human Systems Management, 21(4). 229-240.

14. Sedarmayanti, 2009, Manajemen SDM, Reformasi Birokrasi dan Manajemen Pegawai Negeri Sipil, Bandung: Refika Aditama.

15. Subanegara S. Pengaruh Gaya Kepemimpinan dan Kemampuan Berkomunikasi Kepala Bidang Terhadap Kinerja Pegawai di Rumah Sakit Daerah Sumatra Utaraan [Tesis]. Medan: Universitas Sumatra Utara; 2005.

16. Todaro, 2000. Economic Development, Seventh Edition. NY: University Addison Mesley. 17. WHO. Pelatihan Keterampinan Manajemen SPMK. Jakarta: 2003. 